\title{
KINERJA BADAN NARKOTIKA KABUPATEN DALAM PENANGGULANGAN PENYALAHGUNAAN NARKOBA DI KECAMATAN PANCA RIJANG KABUPATEN SIDENRENG RAPPANG
}

\author{
Rezky Putra Ramadhan \\ Fakultas ilmu sosial dan ilmu poltik Universitas Muhammadiyah Sidenreng Rappang \\ Rezkyputra133@gmail.com
}

\begin{abstract}
Abstrak
Tujuan penelitian ini yaitu untuk mengetahui Kinerja Badan Narkotika Kabupaten (BNK) dalam Penanggulangan Penyalahgunaan narkoba di Kecamatan Panca Rijang Kabupaten Sidenreng Rappang dan faktor-faktor yang memengaruhi Kinerja Badan Narkotika (BNK) dalam penanggulangan penyalahgunaan narkoba di Kecamatan Panca Rijang Kabupaten Sidenreng Rappang. Populasi 26.149 orang di Kecamatan Panca Rijang usia 18 tahun ke atas. Sampel dalam penelitian ini yaitu 100 orang masyarakat Kecamatan Panca Rijang, berdasarkan tehnik purposive sampling atau penetuan sampel dengan kriteria tertentu dengan teknik penarikan sampel menggunakan rumus Slovin. Jenis penelitian ini adalah deskriptif kuantitatif dengan peneletian dasar, penelitian survey dengan tingkat eksplanasi deskriptif, dan jenis data dalam penelitian ini yaitu penelitian kuantitatif, Hasil dari Kinerja Badan Narkotika Kabupaten (BNK) dalam Penanggulangan penyalahgunaan narkoba di Kecamatan Panca Rijang Kabupaten Sidenreng Rappang berada dalam kategori "kurang baik" dengan presentase 55\%. Adapun faktor-faktor yang memengaruhi Kinerja Badan Narkotika Kabupaten (BNK) dalam penanggulangan penyalahgunaan narkoba di Kecamatan Panca Rijang Kabupaten Sidenreng Rappang, Faktor pertama memiliki presentase sebanyak 63\% dengan kategori "Cukup berpengaruh", faktor yang kedua memiliki presentase sebanyak 62,6\% dengan kategori "Cukup berpengaruh", dan faktor yang ketiga memiliki presentase sebanyak 60,6\% dengan kategori "Kurang baik", berdasarkan dari hasil rekapitulasi rata-rata presentase faktor-faktor yang memengaruhi kinerja BNK dalam menanggulangi penyalahgunaan narkoba adalah sebanyak $62 \%$, dan berada pada kategori "Cukup Berpengaruh".

Kata kunci : Kinerja Badan Narkotika Kabupaten
\end{abstract}

\section{Abstract}

The purpose of this study was to determine the performance of the District Narcotics Agency (BNK) in Drug Abuse Management in the Panca Rijang District of Sidenreng Rappang Regency and the factors that influenced the Performance of the Narcotics Agency (BNK) in drug abuse prevention in Panca Rijang Sub-District, Sidenreng Rappang District. The population is 26,149 people in Panca Rijang Subdistrict aged 18 years and above. The sample in this study was 100 people in the District of Panca Rijang, based on purposive sampling techniques or determination of samples with certain criteria with sampling techniques using Slovin formula.. This type of research is quantitative descriptive with basic research, survey research with descriptive explanatory level, and the type of data in this study is quantitative research. The results of the Performance of the District Narcotics Agency (BNK) in the prevention of drug abuse in the Panca Rijang District of Sidenreng Rappang Regency are in the "less good" category with a percentage of $55 \%$. As for the factors that influence the Performance of the District Narcotics Agency (BNK) in drug abuse prevention in Panca Rijang Subdistrict, Sidenreng Rappang Regency, the first factor has a percentage of $63 \%$ with the category "Enough effect", the second factor has a percentage of $62.6 \%$ with the category "Fairly influential", and the third factor has a percentage of $60.6 \%$ with the category "Poor", based on the results of the average recapitulation of the percentage of factors that affect BNK performance in overcoming drug abuse as much as $62 \%$, and are in the "Enough Effect" category.

Keywords:Performance of the District Narcotics Agency

Volume 8 | Nomor 3 | Edisi Desember $2020 \mid$ JIA 


\section{A. Pendahuluan}

Cita-cita bangsa Indonesia sebagaimana tercantum dalam pembukaan Undang-undang dasar 1945 alinia keempat yang berbunyi " Melindungi segenap bangsa Indonesia dan seluruh tumpah darah Indonesia dan untuk memajukan kesejahteraan umum, mencerdaskan kehidupan bangsa dan ikut melaksanakan ketertiban dunia yang berdasarkan kemerdekaan, perdamaian abadi, dan keadilan sosial ". Cita-cita bangsa tersebut, perlu di wujudkan pembangunan nasional disegala bidang kehidupan yang seimbang yang merupakan suatu rangkain pembangunan yang menyeluruh, baik dalam aspek ekonomi, politik, khususnya dalam aspek sosial untuk mewujudkan kehidupan masyarakat yang sejahtera. Masyarakat sejahtera adalah masyarakat yang hidup dengan perekonomian yang baik dan dapat merasakan rasa aman dari segala bentuk penyakit-penyakit sosial yang dapat mengganggu ketentraman kehidupan berbangsa dan bernegara, baik yang merugikan dirinya sendiri maupun yang merugikan orang lain. Masyarakat sejahtera secara umum dapat digambarkan dengan masyarakat yang hidup berkecukupan, aman, damai, dan dapat memberikan kontribusi positif dalam perjalanan bangsa, bukan justru menjadi penghambat dengan melakukan halhal yang bertentangan dengan aturan-aturan Negara.

Narkoba secara etimologi narkotika berasal dari kata "narkoties" yang sama artinya dengan kata "narcosis" yang berarti membius. Sifat dari zat tersebut berpengaruh kepada otak sehingga dapat menyebabkan perubahan perilaku, perasaan, pikiran, persepsi, kesadaran, dan halusinasi disamping dapat digunakan dalam pembiusan. Berdasarkan Pasal 1 ayat (1) Undang-undang Republik Indonesia Nomor 35 Tahun 2009 Tentang Narkotika dapat dilihat pengertian dari Narkotika itu sendiri yakni; "Narkotika adalah zat atau obat yang berasal dari tanaman atau bukan tanaman, baik sintetis maupun semisintetis, yang dapat menyebabkan penurunan atau perubahan kesadaran, hilangnya rasa, mengurangi sampai menghilangkan rasa nyeri, dan dapat menimbulkan ketergantungan, yang dibedakan ke dalam golongan-golongan sebagaimana terlampir dalam Undangundang ini", selain itu di dalam Al-Qur'an menjelaskan dalam surah al-maidah ayat 90 yang berbunyi "Wahai orang-orang yang beriman Sesungguhnya meminum khamar/narkoba, minuman yang memabukan yang dapat menutupi akal sehat (berjudi) mengundi nasib dengan anak panah, adalah perbuatan keji dan termasuk perbuatan setan. Maka jauhilah (perbuatan-perbuatan) itu agar kamu mendapatkan keberuntungan".

Sejalan dengan waktu jika kita melihat situasi dan kondisi kehidupan masyarakat hari ini, khususnya di Provinsi Sulawesi Selatan tercatat angka prevalensi penyalahgunaan di Sulsel tahun 2016 sudah mencapai 130.400 orang. Tidak menutup kemungkinan tahun 2017 hingga tahun 2018 ini mengalami peningkatan, dengan angka penyalahgunaan narkoba ini, menempatkan wilayah Sulawesi Selatan di urutan ke enam dalam penyalahgunaan narkoba di indonesia. Tingginya penyalahgunaan narkoba di Sulawesi selatan menunjukkan peredaran obat obat terlarang di daerah ini semakin bebas diperjual belikan. (Makassar.tribunnews, 2017/09/08). Persoalan terbesar yang dihadapi masyarakat saat ini mulai dari kalangan bawah sampai pada pelaku-pelaku birokrasi adalah masalah penyalahgunaan obatobatan terlarang atau biasa kita dengar di masyarakat adalah narkoba, yang setiap hari menjadi sorotan baik di media cetak maupun elektronik.

Saat ini yang menjadi masalah di Indonesia adalah peredaran dan penggunaan obat terlarang dan narkoba tiap tahunya justru malah bertambah dan semakin banyak kasus yang terjadi. Pecandu narkoba tersebut bukan lagi berada di tingkat usia 25 tahun ke atas justru usia 25 tahun ke bawah pun semakin hari semakin meningkat, karena peredaran narkoba tersebut bukan lagi di kota kota besar tetapi peredaaran/penyalahgunaan narkoba merambah sampai ke pelosok daerah termasuk di Kecamatan Panca Rijang Kabupaten Sidenreng Rappang yang merupakan salah satu tempat peredaran dan angka penyalahgunaan narkoba yang cukup tinggi, terbukti uang tunai $\mathrm{Rp} 6$ milyar diamankan dan $5 \mathrm{Kg}$ Sabu disita oleh petugas Kepolisian Resort Sidenreng Rappang yang di dapatkan di dua lokasi yang berbeda di Kecamatan Panca Rijang yang pertama di ringkus adalah berinisial $(\mathrm{Aa})$ dia ditangkap di rumahnya jalan Andi pangeran 
pettarani Nomor 6 Kelurahan Lalebata, Kecamatan Panca Rijang, Kabupaten Sidenreng Rappang sekitar pukul 04.00 Wita, di lokasi ini petugas menemukan barang bukti sabu seberat $2 \mathrm{~kg}$, ada pula beberapa alat untuk membungkus sabu, dan yang kedua di ringkus berinisial (Ms) diamankan di kediamannya jalan poros PangkajeneRappang, Kelurahan Maccorawalie, Kecamatan Panca Rijang, Kabupaten Sidenreng Rappang, sekitar pukul 07.00 Wita, dari tangan pelaku, petugas menemukan barang bukti sabu seberat kurang lebih $3 \mathrm{~kg}$, barang haram tersebut dikemas dalam bungkusan besar masingmasing 1 kilogram. (fajar.co.id, 2018/07/20)

Berdasarkan observasi awal yang dilakukan oleh peneliti pada bulan Oktober 2018 peneliti melihat ada beberapa fenomena yang ditemukan di lapangan yaitu masih marak penggunaan narkoba di Kecamatan Panca Rijang, oleh karena itu pemberantasan terhadap penanggulangan penyalahgunaan narkoba di Kabupaten Sidenreng Rappang dibutuhkan suatu lembaga yang serius dan mampu menangani permasalahan penyalahgunaan narkoba. Peredaran dan penyalahgunaan narkoba di Kecamatan Panca Rijang masih sangat marak, hal itu di buktikan dari ungkapan tokoh-tokoh masyarakat dan satuan narkoba polres Sidenreng Rappang, mengungkap sedikitnya 115 kasus peredaran narkoba di Kabupaten Sidenreng Rappang, Sulawesi Selatan (sulsel). Sepanjang tahun 2018, selain itu banyak siswa yang putus sekolah di karenakan oleh narkoba, bahkan anak-anak di bawah umur yang dimanfaatkan sebagai kurir untuk mengantar barang haram tersebut. Semakin maraknya peredaran dan penyalahgunaan narkoba di kalangan dewasa dan remaja menjadi sebuah ancaman besar bagi generasi muda.

Sehubungan dengan hal ini pemerintah membentuk Badan Narkotika Nasional (BNN) untuk menangani kasus-kasus narkoba yang ada di negeri ini. Berdasarkan hal itu presiden merubah keputusannya yang sebelumnya disebut sebagai Badan Koordinasi Narkotika Nasional (BKNN) yang dituangkan dalam kepres RI Nomor 17 tahun 2002, tanggal 22 Maret 2002 menjadi Badan Narkotika Nasional (BNN), maka dari itu untuk mengurangi penyalahgunaan narkoba yang ada di lingkungan masyarakat perlu peran suatu lembaga yaitu Badan Narkotika
Nasional (BNN) sesuai dengan Peraturan Presiden (PERPRES) nomor $\neg 83$ tahun 2007 tentang Badan Narkotika Nasional, Badan Narkotika Provinsi, dan Badan Narkotika Kabupaten/Kota. Badan Narkotika Nasional membentuk lembaga di bawah koordinasi BNN yang disebut BNP (Badan Narkotika Provinsi) di tingkat provinsi, BNK (Badan Narkotika Kabupaten) di tingkat Kabupaten dan kota, agar langkah-langkah strategis yang dibuat oleh BNN mampu terlaksana di seluruh sektor publik yang terindikasi terhadap penyalahgunaan narkoba. Keberadaan Badan Narkotika Kabupaten (BNK) yang diharapkan untuk melaksanakan tugas dan fungsi secara maksimal agar pengguna dan peredaran narkoba di Kabupaten Sidenreng Rappang semakin hari mengalami penurunan, tetapi dari hasil pengamatan peneliti di lapangan dan fakta yang kita lihat secara langsung dengan kondisi yang ada justru dengan keberadaan Badan Narkotika Kabupaten (BNK) tingkat pengguna dan peredaran narkoba justru kian hari mengalami peningkatan. Sesuai dengan kedudukan, tugas pokok dan fungsi Badan Narkotika Kabupaten (BNK) adalah unsur penunjang dalam membantu tugas Kepala Daerah dibidang Pencegahan, Pemberantasan, Penyalahgunaan dan Peredaran Gelap Narkoba.

Berdasarkan uraian masalah di atas maka dapat dikatakan bahwa Badan Narkotika Kabupaten (BNK) masih kurang berperan, untuk mengukur kinerja Badan Narkotika Kabupaten (BNK) maka peneliti menggunakan teoeri kinerja yang dikemukakan oleh Dwiyanto (2006) ada lima indikator digunakan untuk mengukur kinerja; (1) Produktivitas, (2) Kualitas Layanan, (3) Responsivitas, (4) Responbilitas,

Akuntabilitas. Sehubungan dengan hal ini maka peneliti merumuskan judul "Kinerja Badan Narkotika Kabupaten dalam Penanggulangan Penyalahgunaan Narkoba di Kecamatan Panca Rijang Kabupaten Sidenreng Rappang" untuk mengetahui KinerjaBadan Narkotika Kabupaten dalam penanggulangan penyalahgunaannarkoba di Kecamatan Panca Rijang Kabupaten Sidenreng Rappang dan untuk mengetahui Faktor-faktor yang memengaruhi Kinerja Badan Narkotika Kabupaten di Kecamatan Panca Rijang Kabupaten Sidenreng Rappang. 


\section{Konsep Kinerja}

Isitilah kinerja berasal dari kata job performance atau actual performance (prestasi kerja atau prestasi sesungguhnya yang dicapai oleh seseorang). Pengertian kinerja (prestasi kerja) adalah hasil kerja secara kualitas dan kuantitas yang dicapai oleh seseorang pegawai dalam melaksanakan tugasnya sesuai dengan tanggung jawab yang diberikan kepadanya. (Mangkunegara, 2013:67). Kinerja berasal dari pengertian performance. pengertian performance sebagai prestasi kerja, namun kinerja memiliki makna yang cukup luas, bukan hasil kerja saja, tetapi bagaiman proses pekerjaan berlangsung. Kinerja merupakan hasil kerjaan yang memiliki hubungan yang sangat kuat dengan tujuan strategis organisasi, kepuasan konsumen, serta memberikan konstribusi pada ekonomi, dengan hal ini maka, kinerja merupakan tentang melakukan pekerjaan dan hasil yang dicapai dari pekerjaan tersebut. sejalan dengan hal tersebut maka peneliti menggunakan teori kinerja yang dikemukakan oleh (Dwiyanto 2006:50-51), menjelaskan ada lima indikator digunakan untuk mengukur kinerja birokrasi, yang dapat dijelaskan sebagai berikut :

a. Produktivitas. Produktivitas yaitu tidak hanya mengukur tingkat efisiensi, tetapi juga mengukur sebagai efektivitas pelayanan. Produktivitas umumnya dipahami sebagai rasio antara input dengan output. Konsep produktivitas dirasa terlalu sempit kemudian General Accouting office (GAO) mencoba mengembangkan satu ukuran produktivitas yang lebih luas dengan memasukan seberapa besar pelayanan publik itu memiliki hasil yang diharapkan salah satu indikator kinerja yang penting. (Agus dwiyanto 2000:48) .

b. Kualitas layanan. Kualitas Layanan yaitu cenderung menjadi penting dalam menjelaskan kinerja organisasi pelayanan publik. Banyak pandangan negatif yang terbentuk mengenai organisasi publik muncul karena ketidakpuasan publik terhadap kualitas. Menurut Dwiyanto, (2002:59) kepuasan masyarakat terhadap layanan dapat dijadikan sebagai indikator kinerja birokrasi publik. Keuntungan dalam kepuasan masyarakat sebagai indikator kinerja yaitu informasi tentang kepuasan masyarakat seringkali tersedia secara mudah dan murah.

c. Responsivitas. Responsivitas yaitu kemanpuan birokrasi untuk mengenali kebutuhan masyrakat, menyusun agenda dan perioritas pelayanan, dan mengembangkan program-program pelayanan publik sesuai dengan kebutuhan masyarakat dan aspirasi masyarakat. Dwiyanto, (2006) Responsivitas merupakan kemampuan organisasi untuk mengidentifikasi segala kebutuhan masyarakat, menyusun prioritas kebutuhan, dan mengembangkannya dalam berbagai program pelayanan.

d. Responsibilitas. Responsibilitas adalah menjelaskan apakah implementasi birokrasi publik dapat dilakukan dengan melihat prinsip-prinsip administrasi dengan benar, kebijakan birokrasi, baik yang eksplisit maupun implisit, (Lenvine dalam Dwiyanto 2006:51). Responsibilitas bisa saja pada suatu ketika berbenturan dengan responsvitas. Menurut (Azheri, 2012:86) responsibilitas merupakan hal yang dapat dipertanggungjawabkan atas suatu kewajiban dan termasuk putusan, keahlian, kemampuan, dan kecakapan.

e. Akuntabilitas. Akuntabilitas merupakan seberapa besar kebijakan atau kegiatan birokrasi publik tunduk pada para pejabat politik yang dipilih oleh rakyat. Asumsinya yaitu para pejabat politik tersebut karena dipilih oleh rakyat, dengan sendirinya akan selalu memprioritaskan kepentingan pubik. sebagaimana yang dikemukakan Jamaluddin (2011) akuntabilitas berarti apa yang dilaksanakan oleh aparat dalam rangka merumuskan kegiatan perencanaan harus dapat dipertanggung jawabkan kepada rakyat, apabila ingin menggunakan prinsip demokrasi.

\section{Konsep Badan Narkotika Kabupaten (BNK)}

Kedudukan, Tugas dan Fungsi Badan Narkotika Kabupaten/Kota. Muhammad Ikbal (2013)

a. Dasar. Keputusan Presiden Republik Indonesia Nomor 17 tahun 2002 tanggal 22 Maret 2002 tentang Badan Narkotika Nasional.

b. Kedudukan. Badan Narkotika Kabupaten adalah Lembaga Non - Struktural yang 
berkedudukan di bawah dan bertanggung jawab langsung kepada Bupati / Walikota.

c. Tugas. Mengkoordinir perangkat daerah dan instansi pemerintah di Kabupaten, dalam mengimplementasikan kebijakan dan pelaksanaan operasional di bidang P4GN (Pemberantasan Pencegahan Penyalahgunaan dan Peredaran Gelap Narkoba).

d. Fungsi. Pengoperasian satuan tugas yang terdiri atas unsur perangkat daerah dan instansi pemerintah di Kabupaten di bidang P4GN (Pemberantasan Pencegahan Penyalahgunaan dan Peredaran Gelap Narkoba) sesuai dengan bidang tugas, fungsi dan kewenangan masing-masing.

\section{Faktor-faktor yang memengaruhi Kinerja Badan Narkotika Kabupaten (BNK)}

Faktor yang memengaruhi sehingga Kinerja Badan Narkotika Kabupaten dapat dicapai dengan maksimal, sehingga faktorfaktor yang dapat memengaruhi Kinerja dapat kita lihat menurut (Anwar, 2000) sebagai berikut:

\section{a. Kemampuan}

Pada dasarnya kemampuan menurut Robbins ( 2002:50), adalah suatu kapasitas individu untuk mengerjakan berbagai tugas dalam suatu pekerjaan. Kemampuan tersebut dapat dilihat dari dua segi: (1) kemampuan intelektual, yaitu kemampuan yang dipergunakan untuk melakukan kegiatan mental, dan (2) kemampuan fisik, yaitu kemampuan yang diperlukan untuk melakukan tugas-tugas yang menuntut stamina, kecekatan, kekuatan dan keterampilan.

\section{b. Motivasi}

Pegawai juga dipengaruhi oleh faktor-faktor birokrasi lingkungan. Pada level departemen, mengaitkan inisiatif dengan kinerja yang diinginkan secara kritis memengaruhi pekerjaan pegawai bahwa kinerja yang tidak akan dihargai dan kinerja yang rendah akan diperlakukan berbeda dengan yang memiliki kinerja tinggi. Kemauan atau motivasi kerja seseorang dipengaruhi oleh beberapa faktor yaitu: (1) pengaruh lingkungan fisik, yaitu setiap pegawai menghendaki lingkungan fisik yang baik untuk bekerja, lampu yang terang, ventilasi udara yang nyaman. (2) pengaruh lingkungan sosial yaitu sebagai makhluk sosial dalam melakasakan pekerjaan tidak semata-mata hanya mengejar penghasilan saja, tetapi juga mengharapkan penghargaan oleh pegawai lain, pegawai lebih berbahagia apabila dapat menerima dan membantu pegawai lain.

\section{B. METODE PENELITIAN}

Jenis penelitian ini menggunakan tipe penelitian deskriftif kuantitaif dengan variabel mandiri yakni variabel $X$. Adapun populasi dalam hal ini yakni, keseluruhan masyarakat kecamatan panca rijang dengan jumlah 26.149 dan menggunakan purposive samplingyakni penentuan sampel dengan pertimbangan tertentu. Dengan jumlah sampel 100 orang. Teknik pengumpulan data yang digunakan yakni observasi, wawancara, kuisioner dan studi kepustakaan serta menggunakan tehnik analisis data dengan bantuan program SPSS for windows, hasil analisis berupa statistik deskriptif, uji kualitas data, analisis deskriptif jenis data interval. Uji Kualitas Data (Uji Validitas dan Reliabilitas).

\section{HASIL DAN PEMBAHASAN}

Berdasarkan hasil rekapitulasi variabel kinerja di atas, dapat dilihat pada tabel menunjukan bahwa dari kelima indikator yakni, produktivitas, kualitas layanan, responsivitas, responsibilitas, akuntabilitas diperoleh hasil $55 \%$ berada dalam kategori kurang baik, maka dapat ditarik kesimpulan bahwa kinerja badan narkotika Kabupaten (BNK) dalam penanggulangan penyalahggunaan narkoba di Kecamatan Panca Rijang Kabupaten Sidenreng Rappang berada dalam kategori kurang baik. Sesuai dengan hasil tersebut dapat dilihat bahwa, Kinerja BNK Kabupaten Sidenreng Rappang belum maksimal utamanya di Kecamatan Panca Rijang sendiri dan masih perlu mengadakan sosialisasi agar penyalahgunaan narkoba dapat di minimalisir utamanya di kalangan remaja.

Hasil rekapitulasi faktor-faktor di atas, dapat dilihat pada tabel menunjukan bahwa faktor yang pertama memliki presentase sebanyak $63 \%$, faktor yang kedua memiliki prenstase sebanyak $62,6 \%$, faktor yang ketiga memiliki prenstase sebanyak $60,6 \%$, dan berdasarkan dari hasil rekapitulasi 
jumlah rata-rata persentase faktor-faktor yang memengaruhi kinerja dalam menanggulangi penyalahgunaan narkoba adalah sebanyak $62 \%$ dan berada pada dalam kategori Cukup berpengaruh.

Berdasarkan penelitian terdahulu dengan judul Akuntabilitas Kinerja Badan Narkotika Kabupaten (BNK) dalam penanggulangan penyalahgunaan narkoba di Kecamatan Panca Rijang Kabupaten Sidenreng Rappang. Masih menunjukan bahwa Akuntabibiltas Badan Narkotika Kabupaten (BNK) masih rendah karna BNK belum mampu melaksanakan tugasnya sesuai dengan apa yang di harapkan oleh masyarakat Kabupaten Sidrap khususnya masyarakat yang ada di Kecamatan Panca Rijang.Uraian diatas, dapat dinyatakan bahwa penelitian ini sejalan dengan penelitian terdahulu dengan hasil yang didapatkan "kurang baik", namun yang membedakan penelitian ini yaitu terletak pada Variabel penelitian dimana penelitian terdahulu meneliti tentang "Akuntabilitas" dan Penelitian ini meneliti tentang "Kinerja.

\section{KESIMPULAN}

Berdasarkan hasil penelitian yang telah di uraikan, maka dapat disimpulkan bahwa :

1. Kinerja badan narkotika Kabupaten (BNK) dalam penanggulangan penyalahggunaan narkoba di Kecamatan Panca Rijang Kabupaten Sidenreng Rappang berada pada kategori "kurang baik" dengan presentase $55 \%$.

2. Faktor yang memengaruhi Kinerja badan narkotika kabupaten (BNK) dalam penanggulangan penyalahggunaan narkoba di Kecamatan Panca Rijang Kabupaten Sidenreng Rappang. Faktor pertama memiliki presentase sebanyak $63 \%$ dengan kategori "Cukup berpengaruh", faktor yang kedua memiliki presentase sebanyak $62,6 \%$ dengan kategori "Cukup berpengaruh", dan faktor yang ketiga memiliki presentase sebanyak $60,6 \%$ dengan kategori "Kurang baik", berdasarkan dari hasil rekapitulasi ratarata presentase faktor-faktor yang memengaruhi kinerja BNK dalam menanggulangi penyalahgunaan narkoba adalah sebanyak $62 \%$, dan berada pada kategori "Cukup Berpengaruh".

\section{H. REFERENSI}

a) Buku
Azheri. 2012. Corporate Social Responsibility. Jakarta: Raja Grafindo Persada.

Ahmad, Jamaluddin. 2011. Perilaku Birokrasi dan Pengambilan

Keputusan. Makassar: Badan Penerbit Universitas Negeri Makassar.

2015. Metode Penelitian Administrasi Publik Teori dan Aplikasi. Yogyakarta: Gava Media

Anogara, Sinungan. 2000. Manajemen Sumber Daya Manusia. Jakarta: Bumi Aksara

Arikunto, Suharsimi. 2013. Prosedur Penelitian Suatu Pendekatan Praktik. Jakarta: Rineka Cipta

Anwar. 2000. Manajemen Sumber Daya Manusia Perusahaan.Bandung: Remaja Rosdakarya.

Bungin, Burhan. 2005. Metode Penelitian Kuantitatif. Jakarta: Prenadamedia

BNN. Badan Narkotika Nasional Republik Indonesia. 23 NOVEMBER 2010.

BNNK. Kegiatan Informasi Penerangan Pencegahan Pemberantasan

Penyalahgunaan dan Peredaran Gelap Narkoba. 2015.

Dwiyanto, A. 2002. Reformasi Pelayanan Publik. Yogyakarta: Pusat Policy Brief

2006. Mewujudkan Good Governance Melalui Pelayanan Publik. Universitas Gajah Mada: Studi Kependudukan dan Kebijakan

Hardiansyah. 2011. Kualitas Pelayanan Publik. Yogyakarta: Gava Media.

Iskandar. 2009. Metodologi Penelitian Kualitatif. Jakarta: Gaung Persada. Keban, Yeremias T. 2008. Enam Dimensi Strategis Administrasi Publik: Konsep, Teori dan Isu. Yogjakarta: Gavamedia. 
2011. Memahami Good Governance dalam perspektif Sumber Daya Manusia. Yogjakarta: Gavamedia.

Muhammad, Ikbal. 2013. Skripsi. Akuntabilitas Kinerja Badan Narkotika Kabupaten dalam Penanggulangan Penyalahgunaan Narkoba di Kecamatan Panca Rijang Kabupaten Sidenreng Rappang. STISIP Muhammadiyah Rappang. Rappang.

Mangkunegara, A.P. 2013. Manajemen Sumber Daya Manusia Perusahaan. Bandung: Remaja Rosdakarya.

Pasolong, Harbani. 2014. Teori Administrasi Publik. Bandung: Alfabeta.

Rivai, V. 2015. Manajemen Sumber Daya Manusia. Jakarta: Raja grafindo persada.

Robbins, Stephen dan Coulter, Mary, 2002. Manajemen. Gramedia. Jakarta.

Robbins Stephen P. 2002. Prinsip-prinsip Perilaku Organisasi. Jakarta: Erlangga.

Sugiyono. 2011. Metode penelitian pendidikan (pendekatan kuantitatif, kualitatif, dan R\&D). Bandung: Alfabeta

2013. Metodelogi Penelitian Kuantitatif, Kualitatif dan R\&D. Bandung: Alfabeta.

Sellang, Kamaruddin. 2016. Administrasi dan pelayanan publik antara teori dan aplikasi. Yogyakarta: Ombak.

Syofian, Siregar. 2015. Metode Penelitian Kuantitatif Dilengkapi Dengan Perbandingan Perhitungan Manual \& SPSS. Jakarta: Kencana

Sembiring, Masana. 2012.Budaya dan Kinerja Organisasi. Bandung: Fokusmedia.

Tangkilisan, H. (2005). Manajemen Publik. Jakarta: Gramedia Widia.
Tuwu, Lahibu. 2012. Disertasi. Pengaruh gaya kepemimpinan, Pengembangan Karir, Motivasi Kerja terhadap Kinerja dan Kualitas Layanan Sumber Daya Manusia Pada Pemerintah Daerah Kabupaten Buton. Makassar: Program Pascasarjana UMI.

\section{b) Jurnal Skripsi}

Sellang, K., \& Darman, M. (2017). Pengaruh motivasi kerja terhadap peningkatan Kinerja Aparatur Sipil Negara di Kantor Kelurahan Manisa Kecamatan Baranti Kabupaten Sidenreng Rappang Provinsi Sulawesi Selatan. AKMEN Jurnal IImiah.

\section{c) Dokumen}

Surah Al Maidah Ayat 90

UU NO 35 Tahun 2009 Tentang Narkotika.

UU NO 83 Tahun 2007 Tentang Badan Narkotika Nasional, Badan Narkotika Provinsi, Badan Narkotika Kabupaten/Kota.

Jumlah data pengguna Narkoba; makassar.tribunnews.com /2017/09/08/ bnn-sulsel.

5-kg-sabu-berhasildisita.fajar.co.id/2018/07/20/mahasiswadan-petani-jadi-bandar-narkoba.

5-kilogram-sabu-di-sidrap ditemukantiga-orang-diamankan.

news.rakyatku.com/2018/07/19/ 